\title{
'By faith alone' (undivided loyalty) in light of change agency theory: Jesus, Paul and the Jesus-group in Colossae
}

\begin{tabular}{|c|c|}
\hline \multicolumn{2}{|c|}{ Author: } \\
\hline \multicolumn{2}{|c|}{$\begin{array}{l}\text { Affiliation: } \\
{ }^{1} \text { Faculty of Theology, } \\
\text { University of Pretoria, } \\
\text { South Africa }\end{array}$} \\
\hline \multicolumn{2}{|c|}{$\begin{array}{l}\text { Research Project } \\
\text { Registration: } \\
\text { Project Leader: A.G. van } \\
\text { Aarde } \\
\text { Project Number: } 2334682\end{array}$} \\
\hline \multicolumn{2}{|c|}{$\begin{array}{l}\text { Description: } \\
\text { This research is part of the } \\
\text { research project, 'Biblical } \\
\text { Theology and Hermeneutics', } \\
\text { directed by Prof. Dr Andries } \\
\text { van Aarde, professor } \\
\text { emeritus and senior fellow in } \\
\text { the Unit for Advancement of } \\
\text { Scholarship at the Faculty of } \\
\text { Theology of the University of } \\
\text { Pretoria, South Africa. }\end{array}$} \\
\hline \multicolumn{2}{|c|}{$\begin{array}{l}\text { Corresponding author: } \\
\text { Andries van Aarde, } \\
\text { andries.vanaarde@aosis.co.za }\end{array}$} \\
\hline $\begin{array}{l}\text { Dates: } \\
\text { Received: } 22 \\
\text { Accepted: } 16 \\
\text { Published: } 26\end{array}$ & $\begin{array}{l}\text { act. } 2016 \\
\text { Aan. } 2017 \\
\text { Apr. } 2017\end{array}$ \\
\hline \multicolumn{2}{|c|}{$\begin{array}{l}\text { How to cite this article: } \\
\text { Van Aarde, A.G., 2017, “'By } \\
\text { faith alone” (undivided } \\
\text { loyalty) in light of change } \\
\text { agency theory: Jesus, Paul } \\
\text { and the Jesus-group in } \\
\text { Colossae', HTS Teologiese } \\
\text { Studies/Theological Studies } \\
73(3), \text { a4355. https://doi. } \\
\text { org/10.4102/hts.v73i3.4355 }\end{array}$} \\
\hline \multicolumn{2}{|c|}{$\begin{array}{l}\text { Copyright: } \\
\text { ( 2017. The Authors. } \\
\text { Licensee: AOSIS. This work } \\
\text { is licensed under the } \\
\text { Creative Commons } \\
\text { Attribution License. }\end{array}$} \\
\hline \multicolumn{2}{|l|}{ Read online: } \\
\hline 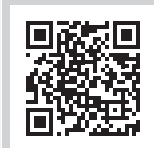 & $\begin{array}{l}\text { Scan this QR } \\
\text { code with your } \\
\text { smart phone or } \\
\text { mobile device } \\
\text { to read online. }\end{array}$ \\
\hline
\end{tabular}

This article aims to apply the model of change agent to the interpretation of Colossians. Presuming a continuity between Jesus and Paul, the article introduces the concept of 'by faith alone' from the Pauline letters. By this expression is meant an undivided fidelity to an inclusive approach to understanding God's work, with concrete historical roots in Jesus' crossing of gender, ethnic and cultural boundaries. Living in this manner requires reformation, transformation and change. The study spells out in fuller detail what is understood 'by faith alone' by discussing the meaning of 'faith' within its semantic domain embedded in the codes of 1st-century Mediterranean culture. Living in faith is both a change of one's inner convictions and about a life in faith.

\section{Intent}

The 500th commemoration of the Reformation cannot but remember Martin Luther (1483-1546) as 'reformer', 'transformer' and 'change agent'. The heart of the change he brought is based on the Pauline expression 'live by faith alone', which pertains to renewal and rebirth on account of an imputation of God. Luther's re-reading of Romans 1:17 (Luther [1515-1516] 1961:18, 105-118), over against Aristotelian scholastics, had a decisive impact on his thinking, which he described as 'an altogether born again'. He says:

There [Rom 1:17] a totally other face of the entire Scriptures showed itself up to me. Thereupon I ran through the Scriptures from memory. I also found in other terms an analogy ... (cited by Heliso 2007:5)

Hoffmann (1983:11), from the Luther Theological Seminary in Oberursel (Germany), describes Aristotle's disposition as that 'when someone does something [s] he acquires a capability and an attribute'. This implies that what humankind 'could previously neither do nor will finally be attained only through continuous trial and practice'. This is a kind of righteousness that is relevant in the 'worldly and political realms' that could 'represents a splendid accomplishment', but before God a 'deception and a Godless hypocrisy' (Luther [1531] 1911, WA 391.82). Paul cautions: do not let your convention cause ruin of one for whom Christ died and do not let your good be spoken of as evil (Rom 14:15-16; my paraphrase and adjustment). Vaino (2008) describes Luther's view as follows:

Renovatio, renewal takes place through union with the person, attributes, and deeds as Christ's life and gifts in the individual [Luther, 1531/1911, WA 40.I, 283, 19-270, 31]. In this sense, there is no separation, or even distinction, between justification and renewal (renovatio). Luther uses the metaphor of the bad tree that is made good in this case. When the nature of the tree is changed, it can now bear good fruit according to its new nature. (p. 39)

According to Luther, there is thus a sequence between Jesus' imputation - which inaugurated change, transformation and reformation - Paul's union with Christ and the participation and continuity by following generations of Jesus followers as change agents. Seen from this perspective this study aims to argue that many key figures in early Jesus movements should be seen as change agents and that a model of change agency can help us that historical and literary interpretations cannot. We therefore ought to consider adopting the 'sequence of generations' - used by John Pilch and Bruce Malina - to complement historical-critical approaches to biblical texts and especially to historical Jesus studies. In this study I demonstrate that the author of Colossians (and the author of Eph) represents a sequence in the trajectory Jesus - Paul - post-Paulinism. The author of Colossians not only preserves a key element of commonality between Jesus and Paul but also prepares a potential way of alienation and departure from Jesus and Paul.

Pilch and Malina applied change agency theory as a social-scientific model to the Corpus Paulinum in 2011 (Pilch 2011:81-99) and 2013 (Malina \& Pilch 2013). Change agency has also been applied to 
the fields of economics and politics (see Caldwell 2003'; Sewell 1992). A change agent relates information from a change agency to a specific group with the aim to mediate change. The change agent facilitates transformation as directed by the agency. The agent is an intermediary between the two entities or structures. Change agency pertains to 'structural change'. Presuppositions with regard to changing structures are a 'multiplicity of structures', the 'transposability ${ }^{3}$ of schemas' and the 'intersection of structures' (Sewell 1992:16). According to Anthony Giddens' 'theory of structuration', structure is not a stagnant entity (cf. Sewell 1992:4). It entails a process. Analogous to de Saussure's ([1916] 1983) distinction between langue and parole, Giddens (1976:118-122) sees structure as consisting of abstract rules. It has a 'virtual' existence, like langue. It manifests in the enactment of these rules in space and time. Like parole, which refers to the production of actual sentences in the practice of speech, the enactment of the rules implies a constant transformation of structure. 'Structure' with its 'virtual' existence, does not place constraints on human agency. It enables human agents to transform the 'very structures that gave them the capacity to act' (Giddens 1976:161; Sewell 1992:4). Sewell (1992:8) prefers the term 'schemas' to 'rules'. Structures are made up of schemas that are 'actualized or put into practice in a range of different circumstances' other than the 'situation in which they are first learned or most conventionally applied' (Sewell 1992:8). For Bourdieu ([1972] 1977) 'habitus' is a durable and transposable structure:

[Habitus is] a system of lasting transposable dispositions which, integrating past experiences, functions at every moment as a matrix of perceptions, appreciations, and actions and makes possible the achievement of infinitely diversified tasks, thanks to analogical transfers of schemes permitting the solution of similarly shaped problems. (p. 83; emphasis original)

The application of change agency theory to biblical exegesis provides a fresh view. Historical and literary interpretations can be enhanced by this focus on the sociological dynamics of the transmission of the Sache Jesu (cause of Jesus). Traditionally, this transmission was explained in terms of the stratification of literary strata and the historical criterion of multiple attestation (cf. Duling 2003:520-523). I would like to honour Malina and Pilch (2013:260-261) for their new direction in historical Jesus research which complements historicalcritical Jesus studies:

$[T]$ here is a very valuable way of dating the sequence of Jesusgroups. This method might be called a generational approach in which ... persons are prominent, not numbers. A generation is marked by new noncontemporary people in a Jesus-group chain. Generations here are not years but chains of people. For Jesus

1.Caldwell (2003:131-212) discusses organisational change from four perspectives leadership, management, consultancy and team models.

2.Regarding 'multiplicity of structures', Sewell (1992) remarks: Structures tend to vary significantly between different institutional spheres, so that kinship structures will have different logics and dynamics than those possessed by religious structures, and so on. There is, moreover, important variation even within a given sphere. For example, the structures that shape and constrain religion in Christian societies included authoritarian, prophetic, ritual and theoretical modes. These may included authoritarian, prophetic, ritual and theoretical modes. These may
sometimes operate in harmony, but they can also lead to sharply conflicting claims and empowerments (pp. 16-17).

3.Anthony Giddens uses the expression 'generalisable' and Pierre Bourdieu, against the background of his notion 'habitus', the expression 'transposable'. movement groups, we obviously begin with Jesus and those about him (Peter and the Twelve; their families; their followers); they mark a first generation. A second generation includes Paul and his co-workers, who followed upon the first Jesus generation but did not experience Jesus. There is nothing in the Pauline writings about what Jesus said and did. This second generation likewise included the other non-first-generation persons mentioned in Paul's letters such as Timothy, Titus, and others. These were second-generation Jesus-group members, or firstgeneration Pauline Jesus-group members.

From a historical-critical perspective Bultmann ([1928] 1969:220-246) explained it in terms of discontinuity of content (inhältliche Diskontinuität) and continuity of intent (sachliche Relation) by which he meant that, though Jesus-followers conceptualised his words differently, they remained true to his intent (cf. Bultmann 1965:191). Marxsen (1976:45-62) also did not see a total breach between Paul and Jesus with regard to the kingdom of God. He coined the phrase, the Sache Jesu geht weiter - the cause of Jesus continues. However, the question is: what is the gist of the Sache Jesu (cf. Van Aarde 2001:148-171)?

Since Ritschl ([1882] [1972] 1999:154-171), it has been generally accepted in Jesus studies that Jesus of Nazareth, ethnically an Israelite crossed a variety of boundaries without being 'un-Jewish'. ${ }^{4}$ The Pauline expression 'by faith alone' is not an abstract truism. It has concrete historical roots (see Jüngel [1990] 1995:82-119) in Jesus' crossing of gender, ethnic and cultural boundaries. How this became a tradition which was conveyed to following generations, is explained in this study by means of change agency theory. In the early Jesus groups 'apostles', who were sent by the God of Israel as Jesus was, acted as 'change agents'. This was known as the 'apostolic tradition'. In their social-science commentary on the deutero-Pauline letters, Malina and Pilch (2013) explained the relationship between the Pauline and deutero-Pauline traditions. I aim to trace this tradition back to Jesus, who lived his entire life 'by faith alone'. No convention was needed. Tolive 'by faith alone' requires radical transformation, that is: change.

\section{Live by faith alone}

With this study I have no intention of reviving a doctrinal

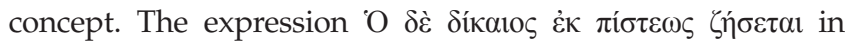
Romans 1:17 contains a citation from Habakkuk 2:4 which does not convey doctrine - also not in the 1st century Stoic sense of the concept dogma (cf. Dunson 2012:77). Martin Luther's ([1538] 1955; in Bouman 1955:801) doctrine of justification ex sola fide (by faith alone) was not grounded solely on Romans 1:17 (cf. Heliso 2007:5-8; Stefon 2011:66, 281) but, in Luther's own words, 'I also found in other terms an analogy'

4.Though 1 accept the hermeneutical assumption that our constructions of Jesus or God are shaped by our own experience, I also take Elliott's (2002:75-93:2003:173God are shaped by our own experience, lalso take Ellott's (2002:75-93; 2003:173210) caution regarding an achronism seriously. According to Elliott, to use a term such as 'egalitarian' is to modernise the early Jesus-followers. My emphasis on the Judeanness of Jesus (cf. Elliott 2007:119-154) and his vision of inclusivity, and Paul's proclamation of the unity of 'believers in Christ', is a deliberate attempt to avoid the hermeneutical fallacy of misplaced concreteness (cf. Bird 2006:310). However though the matter is complex, I will nevertheless endeavour to 'contemporize' the historical Jesus and his earliest followers. 
(Luther [1515-1516] 1961:18, 105-118). Based on Habakkuk 2:4 (LXX) and Pesher Habakkuk (1 QpHab), Smith (1967:13-25) reads $\dot{\varepsilon} \kappa \pi i ́ \sigma \tau \varepsilon \omega \varsigma$ in Romans 1:17 together with the verb 'to live'

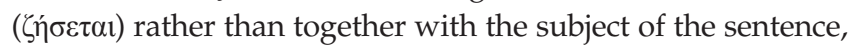

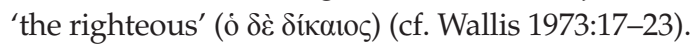

In ancient Greek literature, the $\pi$ í $\tau \imath \varsigma$-word group forms part of the semantic domain 'to trust' and 'to rely on' (Louw \& Nida 1988:376-379). The object of 'confidence', according to Louw and Nida (1988:377), has the qualities of 'being trustworthy' and 'dependable'. Crook (2004:167-1770) convincingly argues that the term 'loyalty', rather than 'faith', should be seen as a better equivalent for the ' $\pi$ í $\tau$ tı-root words'. Should the denotation 'faith' then be abandoned from our religious vocabulary? This is not really a necessity if the connotation 'faithfulness' is semantically and pragmatically embedded in Greco-Roman cultural codes of an honour-shame and patronage-clientalage conceptualisation. Subsequently 'faith' would be understood in a non-doctrinal way as 'fidelity' and 'faith alone' as 'undivided loyalty'.

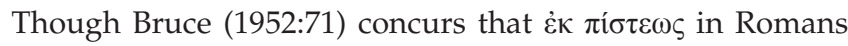
$1: 17$, as citation from Habakkuk $2: 4,{ }^{5}$ should be read together with the verb 'to live' (cf. Bruce [1963] 1985:33), he interprets Pesher Habakkuk (1QP Hab 8:1-13) as that 'his

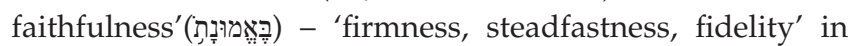
Habakkuk 2:4 - refers to the characteristic of the faithful believer who remains true to the 'Teacher of Righteousness'. ${ }^{6}$

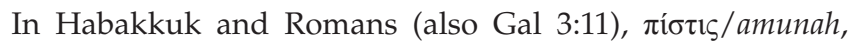
however, refer to God's 'faithfulness' (cf. Ps 98:33-34; Lam $3: 22,23)$, not to that of the believer. Paul's preposition $\dot{\varepsilon} \kappa$ is similar to the Hebrew man lives from or in God's faithfulness' (Wallis 1973:20).

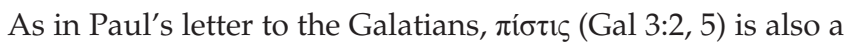
key concept in the letter to the Romans. In Romans 1:5, Paul's

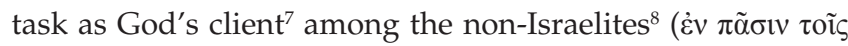

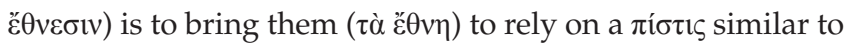
that of the Christ-followers (

5.Bruce (1952:71-72) points to the difference between the free translation of Habakkuk 2:3-4 (LXX - Codex Alexandrinus) in Hebrews 11:37-38 and Paul's use in Romans and Galatians of other LXX versions where 'faithfulness' pertains to God: 'The other LXX authorities read "But the righteous one shall live by faith in me" (ek pisteōs mou, taking mou as objective genitive)' (Bruce 1952:72, note 18).

6.Bruce ([1958] 1959:16) puts it as follows: 'It is plain, too, from the Habakkuk commentary that the Teacher was not only a spiritual leader but a figure of eschatological significance. Acceptance of his teaching, loyally keeping to the path which he marked out for his followers - this was the way to eternal life. So the wellwhich he marked out for his followers - this was the way to eternal life. So the well-
known affirmation of Habakkuk ii 4b, "the righteous shall live by his faith", is known affirmation of Habakkuk ii 4b, "the righteous shall live by his faith", is
explained thus: "Its interpretation concerns all the doers of the law in the house of Judah, whom God will save from the house of judgment because of their labour Judah, whom God will save from the house of judgment because of their labour
('ämäl) and their faith in (or faithfulness to) the Teacher of Righteousness"' (1Q p ('àmāl) and their
Hab. viii 1-3)

7.Crook (2005:20-25) describes Paul's 'apostolicity' in terms of ancient Mediterraneans' understanding of patronage and clientage.

8.According to Malina (2002): "'Gentile" (Greek: ع̈ $\theta v \eta$ ) means "peoples", various populations defined by common genealogy. The word is the Israelite in-group designation for all peoples other than Israel. Thus in Paul's collocation the $\ddot{\varepsilon} \theta \mathrm{v} \eta$ means everyone who is not a Judean. These categories are quite demonstrative of ancient Israelite values' (p. 614)

9.Esler (2003) puts it as follows: '... Paul is not writing to Christ-followers in Rome who are at risk of having themselves circumcised and joining an Israelite out-group, but rather is sending a letter to the Christ-movement in the city that is experiencing internal problems, notable those involving tension between Judean and non-Judean members. Above all, Paul is trying to bring them together by reminding them of a members. Above all, Paul is trying to bring them together by reminding them of
single category they have in common - faith and righteousness in Christ' (p. 26). forms an inclusio with Romans 16:26 (cf. Brown 2012:62-78). ${ }^{10}$ Because God is one, God brings both Judeans and non-

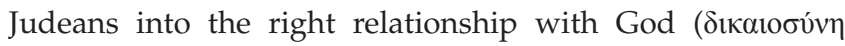

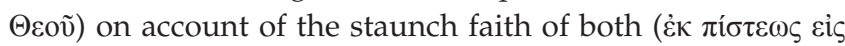
$\pi i \sigma \tau ı$ ) (cf. Moxnes 1988:69). ${ }^{11}$ The gospel that Paul proclaims without shame is the power of God through which both

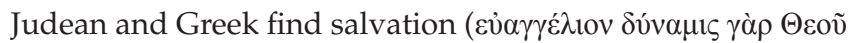

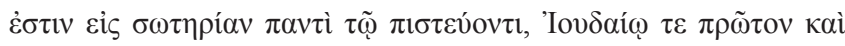
"E $\lambda \lambda \eta v r$ - Rom 1:16). Paul's mission is to bring non-Judeans

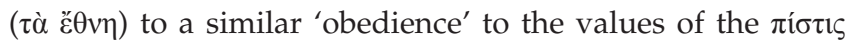
than that of the Judeans. The in-group of Christ-followers and the out-group should share a similar ethos (formulated

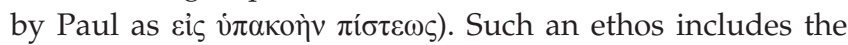
eradication of enmity, alienation and socio-cultural boundaries between the in-group and the out-group. This is

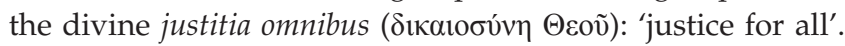
Such an ethos requires a radical detachment from the conventional lifestyle and traditional adherence to the socialreligious symbolic universum of the Israelite in-group. In other words, Paul's understanding of the divine justitia omnibus contests Artistotle's idea of justitia civilis (cf. Hoffmann 1983:11).

For Paul 'faith in God', that is fidelity and loyalty to God, means trust in God as 'Totenerwecker' (Hahn [2002] 2005:268). In Romans 4:24, faith is trusting in God who

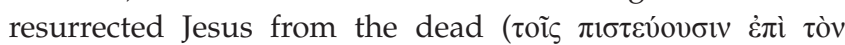

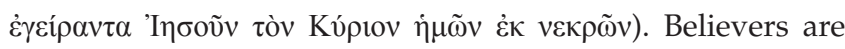
inspired to accept this creatio ex nihilo - an act of recreation -

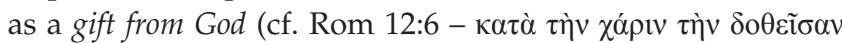
$\eta \mu i \tau)$. According to Crook (2005), seen from the perspective of patronage and clientage, it:

might be the case that Paul changed brokers from Moses (or perhaps from the priestly cult) to Jesus - though this would be difficult to prove .... The subsequent changes in Paul's behaviour (1 Cor 15:8; Gal 1:13-15; 22-24; Phil 3:8) were the natural extension of having a new brokers as well as discovering that God was to be pleased and honoured in a new manner. (p. 18)

Faith requires for Paul a 'renewal of mind' (Rom 12:2). On the one hand it is a 'remaking' /'metamorphosis' ( $\mu \varepsilon \tau \alpha \mu \rho \rho \varphi о \tilde{\sigma} \theta \varepsilon)$

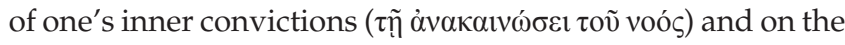
other hand it is about a life in faith (in accordance with the

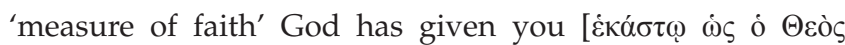

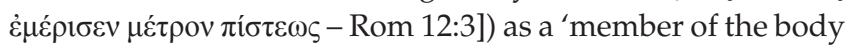
of Christ' (غ்vi $\sigma \omega ́ \mu \alpha \tau \imath-R o m ~ 12: 4)$. Those who trust God believe that they have been resurrected to live an ethos in spite of

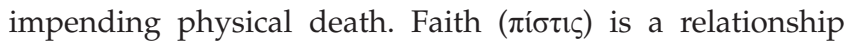
based on trust (Hahn [2002] 2005:269) and a gift from God.

10.Brown ([2012]:62-78) summarises the exegetical opinions on the meaning of "the obedience of faith' as follows: Paul uses the phrase "the obedience of faith" to frame his letter (1:5, 16:26), forming an inclusio, which gives the phrase central importance for understanding Paul's rhetorical ends. There is much debate surrounding the genitival relationship of this phrase ('unto the obedience of faith'). There are three proposals that carry the most weight. First, faith may be understood as an adjectival genitive meaning 'faith's obedience' or 'the obedience as an adjectival genitive meaning 'faith's obedience or the obedience characterized by faith. Second, and the majority view, is that this is a genitive of apposition, 'the obedience which consists in faith'. A third option is a subjective
genitive, 'obedience'.

11.Malina (2002:608): 'Non-Israelites simply did not fit into the divine plan of things until non-Israelites, some centuries later, began to identify with Paul's "we" something Paul did not foresee' (Moxnes 1988:69). 
Though Jesus' understanding of death as such differed from Paul's understanding of Jesus' death, his words and deeds were compatible with how Paul formulated it. For Jesus, undivided loyalty and obedience to the will of God can result in the tragedy that one could be killed. At least, such an absolute compliance with what God demands compels selfdenial, however, for the benefit of others. With retrospection, Paul interpreted Jesus' death as a deed of redemption; a deed 'for us' (pro nobis). By inference, one can say Jesus' understanding of his followers' deaths is compatible with Paul's understanding of the death of Jesus' followers. The life of Jesus was condensed in his death. Mark's understanding of Jesus' directive that his followers take up their cross and die in order to gain life (Mk 8:34-37) is the core of the message that God creates new life when one dies to this aion (Rom 6:2-11). According to Jesus, authentic life was not to be found in pleasing people, but in doing God's will (Mk 8:33). It cannot be found in conventions, culture, ethnicity or anything from this world. Jüngel (1962:266) describes Romans 1:17 as a

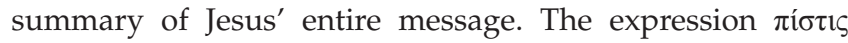

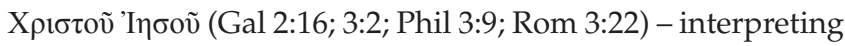

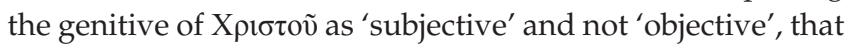
is the faithfulness of Christ Jesus and not faith in Christ Jesus - refers to the Jesus followers' understanding of Jesus' 'willingness to die, to follow on God's plan for him despite the cost' (Crook 2004:175). Seen that the $\pi i \sigma \tau-$ and $\alpha{ }^{\prime} \pi \sigma \tau-$ words are framed 'in categories of patronage and clientage', Crook (2004:175) interprets these semantic domains as,

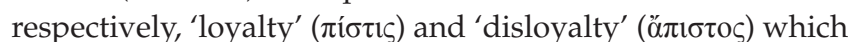
'were the backbone of changes or continuity' in 'relationships between ancient Mediterranean people and their gods and/ or philosophical leaders'.

In his book, Paul $\mathcal{E}$ his world: Interpreting the New Testament in its context, Koester (2007:12-14) proposes criteria for the ethics and morality of the 'new community' of Christfollowers. Any community would employ legal means to prevent crimes such as murder, robbery, prostitution and the like. However, what is of central concern to Christ-followers specifically is the relationships among 'brothers and sisters' in the new 'regenerated' community. The question is whether they succeed in realising God's righteousness in this world. The principle that is most compelling to Christ-followers is 'to follow the commandment of love regardless of all distinctions of ethnic, social, and gender identity'. According to Koester, Paul did not establish a 'new religion' consisting of yet another system of identity boundaries and exclusivism. One can argue that in 1 Corinthians 5:1-5 and Galatians 5:12, Paul is drawing boundaries and that it is a matter of piety and morality when Paul in Romans 12:2 speaks of a renewal of mind and a remaking of one's inner convictions. Yet, I understand Koester (via Bultmann - see Van Aarde 2015) that for Paul it is not about the development of a personal piety and moral sensitivity which could lead to an attitude of moral superiority. Koester explains Paul's intent as follows:

It is a new just society that the apostle envisages. Personal righteousness, piety, and moral achievements no longer matter. Justice and righteousness belong to God ... God is love, and his justice becomes a reality among all those who venture to accept this offer by becoming members of the new worldwide community of those who love each other and care for each other regardless of any racial, ethnic, gender, sexuality, and socialstatus distinctions. Righteousness as personal piety and morality only creates divisions within a society and among nations. The justice of God cannot be realized in this way. It can become real already here and now in a society without hierarchs who try to enforce divisive moral obligations, and without the borderlines of traditions that are reinforced by pious self-righteousness. God's righteousness is the gift of freedom - even freedom from piety and particularly from moral self-righteousness. It requires the establishment of justice among people who are free to abide by the standards of mutual respect, equality, and carrying one another's burdens.

An active 'life in love' is, according to Koester (2007:14), more important to Paul than either passively:

receiving the divine gift of righteousness as 'absolution' in the juridical sense of the word (according to Gal 5:6, 'faith works through love' [cf. Bruce [1963] 1985:103], or a self-righteous obedience to legalistic cultural and religious conventions.

'Faith alone' (i.e. undivided loyalty) is not the central theme of Paul's theology, but rather the dialectic 'flesh' ( $\sigma \alpha \dot{\rho} \xi)$ and 'spirit' ( $\pi v \varepsilon \tilde{u} \mu \alpha)$ (cf. Bruce [1963] 1985:38-39). 'Faith alone' should be understood as a tenet ( $\delta$ ó $\gamma \mu \alpha$ - in the ancient Greek sense of the word) that is based on Paul's conviction that the death of Jesus means dying to the law - be it tradition, cultural or cultic - and that the resurrection is the beginning of the 'new person' (2 Cor 5:17). For me it is not a matter of

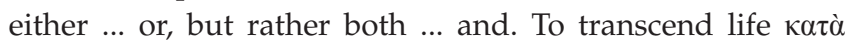

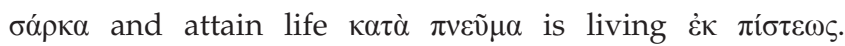
Furthermore, 'faith alone' is not limited to Pauline literature. It can also be found in the gospel tradition and beyond. According to Bruce (1952), it appears in Mark, Hebrews and James.

Resurrection faith and its ethical implications featured prominently among 1st-century Christ-followers influenced by Paul. The crux of this faith is conveyed in the expressions $\dot{\varepsilon} \kappa \pi i ́ \sigma \tau \omega \varsigma$ and $\kappa \alpha \tau \grave{\alpha} \pi v \varepsilon \tilde{u} \mu \alpha$. How this ethos survived can be explained by means of change agency theory. In their commentary on deutero-Pauline literature, Pilch and Malina (2013:9) describe Paul as a 'change agent' who articulated the resurrection faith for Christ-followers:

As change agent successors focused on Israelites living among non-Israelites, Paul's assistants continued to proclaim the mystery that the God of Israel was about to bring redemption or restoration of honour to Israel. The message was a solution to an Israelite problem. The problem was Israel's situation outside Judea (and in Judea). Paul was one of those who believed that God's raising Jesus signalled Israel's forthcoming redemption. Hence, the people Paul approached were an Israelite minority living in Hellenistic societies. And the message to his fellow Israelites was that God's redemption of Israel has dawned by means of Israel's Messiah raised by God, Further, his Jesus has been exalted by God. In these post-Pauline letters, this Jesus is now cosmic Lord. The Israelites who found this message a solution to their problem of being Israelites in the first century 
would fit this information into their traditional and ancestral kinship religion. (pp. 9-10)

In Romans 12:1-13:14 Paul, as a 'Jesus-group prophet' (Gal 1:15) (Malina 2002:608) expands on what Malina and Pilch (2006:275-282) call 'Jesus-group values'. Paul describes the 'group task' that God expected them to fulfil as $\chi \alpha \rho 1 \sigma \mu \alpha \dot{\tau} \alpha$. This 'group task' was aimed at enhancing the well-being of the group as a whole. ${ }^{12}$ Such an advantage for all is a 'typical collectivistic appreciation of the primacy of group integrity over individualistic self-reliance'. According to Malina and Pilch (2006:177), this is what Paul had in mind when he used the expression 'one body in Christ and

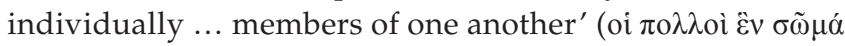

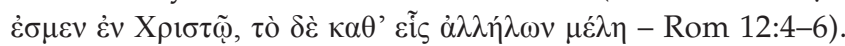
As a 'Jesus-group prophet' Paul not only transcended the interests of individuals belonging to the in-group but also the interests of the whole in-group which tended to exclude the out-group (contra Malina). Such a transcending and transformative ethos is subversive with regard to the prevalent social tradition of 'separateness' (akin to 'apartheid') in Mediterranean and other cultures. ${ }^{13}$

Though a similar trend can be identified in 1st-century Stoic philosophy of universal inclusivity (cf. Van Aarde 2014:2 of 11), this ethos is distinctive to Jesus of Nazareth and his 'prophet', Paul. One of the most notable subversive pronouncements in both the Jesus tradition and the Pauline tradition is loving one's neighbour. A concrete example is turning the other cheek when slapped by someone from either the in-group or the out-group (Q 6:29 / / Mt 5:39 / / Lk 6:29). Paul's version is that when an aggressive act is met with love, that love becomes like burning coals - burning the enemy with shame (Rom 12:20; cf. Ecc 25:21-22). This points to an ethos that transcends the in-group (cf. Van Aarde 2012:43-68).

Romans 12 does not provide many clues as to the interdependence of the ethos of Jesus (as, e.g. expressed in the Sermon on the Mount and based on the Sayings Source Q) and Paul. Jewett (2007:779) sees Romans 12:9-21 as a 'discourse on "genuine love"', which represents a 'transformative framework that is universal in scope, but local in operation'. From a traditional historical critical perspective, the relationship between Jesus and Paul has been understood primarily in historical and literary terms. Exegetical traditions refer to it as a probable (Allison 1982:11-12; Dunn 1988:745, 1990:201; Stuhlmacher 1983:240 250; Thompson 1991:96-105) or an improbable relationship (see Neirynck 1986:265-321; Walter 1985:501-502). Wenham (1995:251) speculates that Paul built on an unknown Jesus tradition and that Luke, who was influenced by Paul, contributed further to the Pauline tradition. Wilson (1991:165-171) and Zerbe (1992:207-208), on the other hand,

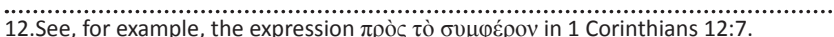

13.This analogy with an 'apartheid social structure' is also drawn by Bruce Malina in his paper, 'We and they in Romans', presented at the first South African International Context Group Meeting in 2001 at the University of Pretoria (cf. Malina 2002:629). find that Paul may have cited from the Didache or some unknown Judean (or Judaeo-Christian) wisdom tradition (cf. Jewett 2007:766, note 103).

Over against such speculative exegesis, I find Pilch and Malina's use of 'change agency theory' and their innovative social-scientific critical understanding of the transmission of the Jesus tradition particularly valuable. The application of this social-scientific theory confirms the continuity between Jesus and Paul (including certain post-Pauline documents), specifically with regard to transcending an in-group mentality and adopting radical inclusivity and love as the distinctive ethical values of the Jesus-group. It is my conviction that the roots of such a transforming ethos which reaches across generations not only lie in the Pauline concept 'faith alone' but can also be traced back to the historical Jesus.

Where 'faith alone' (undivided loyalty) was not central to the thought of some early Jesus-groups, it led to two thought constructs. One is the revival of an apocalyptic retribution mentality regarding the out-group. Post-Pauline 2 Thessalonians is an example of this (cf. Van Aarde 1996:237-266). The other is the re-institutionalisation of the Jesus-group in terms of patriarchal and hierarchical 'in house' systems. In certain postPauline writings, both resurrection faith (the ethos of 'faith alone'/'undivided loyalty') and the opposing patriarchal household codes are to be found, for example, Colossians 3:184:1; Ephesians 5:22-6:9 and 1 Peter 2:18-3:7. In the Pastoral

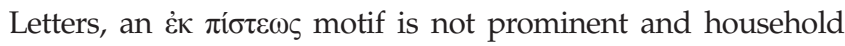
codes (1 Tim 2:8-15; 6:1-2; Tit 2:1-10) are not relativised by an emphasis on the value of 'faith alone'.

Theissen (1982:107-108) describes this as 'moderate conservatism', which takes 'social differences' for granted, but 'ameliorates them through an obligation of respect and love, an obligation imposed upon those who are socially stronger'. Building on the work of Troeltsch (1912:67-83), he describes this departure from Paul (and Jesus) as 'lovepatriarchalism' (Liebespatriarchalismus) or 'love-communism' (Liebeskommunismus) (Theissen 1995:689-711). ${ }^{14}$ In his 1999 book, A theory of primitive Christian religion, Theissen (1999:9899) calls this a 'reversal of power relations'. ${ }^{15}$ Traces of both mentalities (love-patriarchalism and an apocalyptic desire for vengeance) can be seen in interpolations into authentic Pauline letters, such as 1 Corinthians 14:33b-38 and Romans 5:6-7 (cf. Dewey et al. 2010:112, 253 resp).

14.In the German original of Theissen's 1982 book, Theissen ([1979] 1989.102 note 67) cites Troeltsch (1912) as follows: Er ist der auf religiöse Anerkennung und 67) cites Troeltsch (1912) as follows: Er ist der auf religiöse Anerkennung und
religiöse Überwindung des irdischen Ungleichheit zugleich begründete Typus der christlichen Patriarchalismus, der seine Vorbereitung im spätjüdischen gehabt hat, aber durch die Wärme der christlichen Liebesidee, durch den Zusammenschlu $\beta$ aller in dem Leibe Christi, seine besondere Färbung erhält (p. 67).

15.Troeltsch (1912:68) refers to the 'Grundidee der willigen Akzeptierung der gegebenen Ungleichheiten und ihrer Fruchtbarmachung für die etischen Werte der persönlichen Aufeinanderbeziehung'.

16.Jewett (2007): '[ $T$ ] he text-critical evidence suggests the possibility that this verse [Rom 5:7] was a later gloss or perhaps two glosses'. The word $\mu$ ó $\lambda$ ıs [hardly') in v. [Rom 5.7] was a later gloss or perhaps two glosses. The word $\mu$ o $\lambda$ is (hardly') in v. 7 never appears elsewhere in Paul's letters ... Schneider [in Jewett 2007:359 note 144] notes that the term has no single Hebrew equivalent, and appears only in Pro 1:31; Wis 9:16; Sir 21:20; 26:29; 29:6; 35:7; 3 Macc 1:23; 5:15 .... Isocrate [Archidamus 107 - in Jewett 2007:360 note 360 ] states that 'if we are willing to die for righteous things ..., not only will we be approved of, but it shall also in the future be permitted to live most securely' (pp. 359-360). 
I will now explain Colossians from the perspective of change agency theory. The discussion will conclude with an illustration from Colossians and Ephesians. Ephesians used Colossians as an important source. ${ }^{17}$

\section{Change agency theory applied to Colossians}

Change agents do the following (Malina \& Pilch 2013:235238): (1) create awareness of a need for change, (2) exchange information, (3) identify and explain the problems, (4) motivate for change, (5) initiate change, (6) stabilise and prevent discontinuity and (7) terminate the relationship.

\section{Change is vital}

A change agent creates awareness that there are alternatives to the problems of the community. In Galatians 1:7 and 1 Corinthians 10, Paul names the opposing groups directly and expresses his displeasure at their efforts to sabotage his work. In Colossians, on the other hand, the opposing points of view are identified without reference to specific people. Colossians also does not refer to the financial needs of the Jesus-group to whom the letter is addressed. ${ }^{18}$ The author as change agent makes the group aware of what their problems are. The reason for his writing of the letter could have been their anxiety. It seems as though a crisis caused uncertainty among the members of the Jesus-group in Colossae, which led to conflict among themselves (cf. Stuckenbruck 2005:2819). The group was possibly brought together on the initiative of Epaphras (Col 1:6-8). It can be seen as a 'house church' (Col 4:15). The household codes (Col 3:18-4:1) indicate that slaves and children were seen as part of the group. The group consisted of Judeans and non-Judeans of which the latter was the majority (cf. Dunn 2009:1037). The non-Judeans are made aware that, because of Jesus, the Messiah, they now had access to religious privileges previously reserved for the Judeans (Col 1:12, 27; 2:13). All people - Greeks and Judeans, circumcised or not - could trust that God would liberate them because of Jesus the Messiah (Col 3:11; 4:11).

\section{Exchange of information}

The change agent assures the group that they, as heirs, will receive God's liberation. This includes liberation from the power of darkness and initiation into the kingdom of the Son of God (Col 1:12-14). What is said about the Messiah serves to strengthen the self-image of the group. In light of the values of the Messiah, cultural and traditional demands have

17. More than a third of the 155 verses in Ephesians have parallels in Colossians, both regarding syntactical order and semantic content. Collins (1988) refers to the relationship between these two post-Pauline letters as follows: The form in which Ephesians has been handed down is the nub of the problematic relationship Ephesians has been handeric relationship between Ephesians and Colossians. consider, and vocabulary of the two upon the other (p. 143). However (Lohse [1968] 1971), although: '[l]n certain passages Ephesians reads like the first commentary on Colossians, though admittedly it does more than explicate the thoughts of Colossians: it also expands them into concepts of its own' (p. 4).

Due to the limited scope of this contribution the phases of the transformation that develops from Colossians through Ephesians cannot be discussed in detail.

18.Examples of specific material need referred to in authentic Pauline letters are 1 Corinthians 16:1-4; 2 Corinthians 8-9; Galatians 2:10 and Romans 15:26. become irrelevant (Col 2:8-23). This includes social prescriptions regarding 'food, drink, and the observance of certain days (Col. 2.16)' (DeMaris 1994:57) as well as cultic purity (Col 2:20-23) - however, 'the drive for purity goes beyond the cultic and ritual practices typical of Judaism' (DeMaris 1994:58).

\section{Motivation for change}

The hymn about the Messiah (Col 1:15-20) motivates the group to remain strong in hope and trust. Lohse ([1968] 1971: 103-105, 182; cf. Collins 1988:185) points out similarities between the Jesus-group in Colossae and Rome (Col 1-2 and 3-4; Rom 1-11 and 12-15). However, the letters were intended for different Jesus-groups which consisted of people from different generations (cf. Duling 2003:263-264). The theme of death and resurrection grounded in the baptism of Christ features in both Romans (6:1-11) and Colossians (2:11-13). ${ }^{19}$ The change agent's conceptualisation of time (eschatology) is based on his view of baptism as resurrection with Christ (Col $2: 12 ; 3: 1)$, to the extent that the person who has been baptised is 'already in heaven' or at least in the sphere of liberation, the church, the body of Christ. In such a 'Christologicalcosmological ecclesiology', the exalted Christ is the head of the body (Col 1:18; 2:10, 19) who brings all believers together in fellowship (Col 1:18, 24).

\section{Identification of matters of concern}

The letter to the Colossians gives clues as to the readership, namely that the intended audience were non-Judeans (Col $1: 21,27 ; 2: 13 ; 3: 5,7)$. The author did not know them personally (Col 2:1), since this 'house church' was not founded by him. It was founded by Epaphras, a non-Israelite (Col 4:12), who had a different understanding of the gospel than the author of Colossians (1:23). This he conveyed to the congregation (Col 1:7). On the one hand the gospel message did bear fruit among them (Col 1:3-8), but there were also false teachers who were misleading them ( $\mathrm{Col} 2: 4,8,16-18)$. The believers accepted the teachings of the false prophets and adhered to their prescriptions (Col 2:20-23).

Colossians, especially in Chapter 3, emphasises that following the Messiah means that their lives have changed radically. In Christ they have died to the world and what is of the world. The change agent author stresses that creation centres on the Messiah and reaches its highpoint in reconciliation. He is the head over everything because he existed before anything. $\mathrm{He}$ brought peace through his blood on the cross. Twice (Col 2:12 and 3:1) the change agent points out that believers have been resurrected with Christ and therefore their lives should reflect the values of the Jesus-group.

\section{Initiating change}

Characteristic of the change agent is his petition that believers should adapt to changed circumstances - the Messiah's

19.0ther elements that are central to Pauline theology, such as the second coming of the Lord, the resurrection of the body and the final judgement are absent from Colossians. 
presence in the world (Col 1:10; 2: 20). He emphasises that freedom is characteristic of the new lifestyle. This contrasts strongly with an ascetic life regulated by demands that are foreign to the values of the Jesus-group (Col 2:20-21). Collins (1988) puts it as follows:

Now, there is a new situation, for Christians have been delivered from the dominion of darkness and share in the inheritance of the saints of light (Col 1:12-13). Light characterizes the domain in which God has placed these Christians because of the mediatorial action of Christ. (p. 198)

The change agent in Colossians goes further than Paul in seeing the resurrection of the believer with Christ as already fulfilled. In Colossians 2:12-13, it is said with reference to baptism. In Colossians 3:1, it is repeated and qualified with 'hidden with Christ in God'. With this the author emphasises the reality of the new life as well as its mystery and incomparability. The new life is not just a given or a static characteristic of believers. Because of its mystery and incomparability, they should 'seek the things that are above' and not set their minds on 'things that are on earth' (Col 3:1-2). A further consequence is that believers' lives should correspond with this new reality. The content of Colossians 3:1-4 forms the basis for Colossians 3:5-17 in which the implications of being resurrected with Christ are worked out.

In Colossians 3:5-17, the old and new life are contrasted in a concrete way. This section consists of two parts. The first (Col 3:5-11) is about how the old life should be left behind and the second (Col 3:12-17) is about how the new life should be lived. The life of the Jesus-group is hidden with Christ in God (Col 3:3). There is no more room for earlier practices, specifically behaviour that harms other believers and threatens the unity of the Jesus-group. Jesus-followers who live a new life are renewed according to the image of their Creator. Here the thinking of the change agent in Colossians and that of Paul as the 'prophet of the Messiah' intersect. According to Paul, believers who behold the glory of Christ are being transformed into the same image (2 Cor 3:18; cf. Gal 4:19). What Paul had in mind here is in keeping with what the author of Colossians explains: followers of Jesus are recreated to become new persons who should live their lives accordingly. New life means sharing in the resurrection of Christ (Col 2:12-13). The record of debt that stood against them with its legal demands has been cancelled (Col 2:13-14).

\section{Stabilisation of continuity}

One can argue that the household code in Colossians is but the stabilising rhetoric of the change agent. Except for the words 'the Lord', 'Christ' and 'the Lord in heaven', nothing reminds of the values of the Jesus-group. There are, however, two differences with the common Hellenistic household codes of the time. The first is that the Hellenistic household codes refer to deities, country, family and friends. The second is that Hellenistic household codes only addressed the husband, father or owner as an adult and agree person. Women, children and slaves were not regarded as such.
In Philo (De Decalogo 165-167) and Josephus (Contra Apionem 199-210), they are addressed as 'couples' in household codes along with the husband, father and owner for the first time. Changes regarding the social value and dignity of women, children and slaves as could be seen in the Jesus-groups and were articulated in documents such as Colossians only became more general in the social world much later.

These later social changes can most certainly be attributed to the influence of the historical Jesus and his followers regarding how the lowly and marginalised should be treated. Notably, there are no household codes in authentic Pauline letters. The change agent author of Colossians aims to convince the 'house church' that everything has changed. They were resurrected with Christ and should set their minds on things that are above, not on things that are on earth (Col 3:1-2). The old life has passed and the new life is hidden with the Messiah in God (3: 3). Their life now reflects the Messiah as an image of God. In this image they have been renewed (Col 3:10). The ethos that follows is that all people are equal in Christ and all forms of discrimination are to be removed (Col 3:11). Appeals for compassion (Col 3:12), forgiveness and love (Col 3:13-14) are characteristic of the Jesus-tradition.

\section{Terminating relationship}

The change agent in Colossians is, however, also the reason why this particular Jesus-group moves away from the values of the Messiah. This is the result of his uncritical tendency towards institutionalisation, which can be seen in his use of the Hellenistic household code (Col 3:18-4:1). Such household codes are not to be found in authentic Pauline writings. One could then argue that the change agent conformed to the world around him for the sake of peace and harmony, trying to assuage conflict in this particular Jesus-group. It is notable that the oppositional pair, 'man or woman', is absent from Colossians 3:11, which is clearly based on Galatians 3:28 Greek or Judean circumcised or not circumcised, and the like.

The change agent in Colossians seems to have adapted Galatians so as that its equal treatment of man and woman would not contradict the household codes, which required the submission of women.

Should this observation be accurate, it constitutes a postPauline reaction against the inclusivity of Paul, which ended up as 'love-patriarchalism'. The dominant position was yet again allocated to males. This is an anomaly with the change agent's message that they should not be misled or be dictated to by opposing Jesus-followers who could not or would not transcend the exclusivity of the in-group (Col 2:4, 8, 16). Such a thought construct is also contrary to his exhortation that his readers should be rooted and built up in Christ (Col 2:6-7; cf. 2:19). Such a deviation constitutes a termination of the relationship with the values of the Jesus-group that go back to Paul and the historical Jesus. According to Rogers and Shoemaker (1971:337; cf. Malina \& Pilch 2013:238), change agents: 
are especially likely to make this mistake (that is, not anticipate consequences in meaning) when they do not empathize fully with the members of the recipient culture, as in cross-cultural contacts or in other heterophilous situations.

\section{Epilogue}

My view that 'faith alone' /'undivided loyalty' is die core of the trajectory from Jesus, to Paul, to the deutero-Pauline writings Colossians and Ephesians, differs from that of Malina and Pilch (2013). Though for them the resurrection belief is also fundamental, it does not constitute the nucleus of the transformation (change) inaugurated by the Jesusevent. According to them, the innovation conveyed to the post-Pauline Jesus-groups consists of two elements: the preservation of a 'forthcoming theocracy' and (an eschatological) 'forthcoming redemption'. This was meant for Israel alone. They put it as follows (Malina \& Pilch 2013):

The innovation that Jesus proclaimed, on the one hand, was forthcoming Israelite theocracy or the kingdom of heaven/God. The innovation that Paul proclaimed was that the God of Israel raised Jesus from the dead, thus revealing Jesus to be Israel's Messiah (Christ) and cosmic Lord, with a view to the forthcoming Israelite theocracy (1 Thessalonians and frequently). According to these New Testament witness, then, the founder or change agency of Jesus-groups and their ideology is God, the God of Israel ... Paul was one of those who believed that God's raising of Jesus signaled Israel's forthcoming redemption ... And his message to his fellow Israelites was that God's redemption of Israel has dawned by means of Israel's Messiah raised by God. Further, his Jesus has been exalted by God. In these post-Pauline letters, this Jesus is now cosmic Lord. (pp. 8-10)

According to Malina and Pilch's perspective, Theissen's notions of 'love-patriarchalism' and 'obligation of respect and love' could be applied to the Jesus-group, but they would limit it to the Israelite in-group.

Two responses to the Liebesidee promoted by Gerd Theissen are notable. For Schottroff ([1985] 1999:275) Theissen's view of an almost universal 'love-patriarchalism' in the postPauline communities is 'an historically inaccurate impression of the character of the early Christian communities'. However, her characterisation of the post-Pauline Jesusgroups as 'communities of the poor' is also too generalised. According to Syreeni (2003:419), Paul is not 'blameless' when it comes to the post-Pauline 'patriarchal' reception of Liebeskommunismus. He regards the hierarchically structured household codes (Haustafeln) as a Pauline heritage - not only of the deutero-Pauline Jesus-groups. Even when one accepts Paul as a child of his time,,$^{20}$ as he does, the ethos of 'faith alone' /'undivided loyalty', 'dying with Christ' and a 'renewal of life' that he advocates is not congruent with

20.Schottroff ([1985] 1999:419) refers to Antoinette Clark Wire's experience when she came across the 1754 will of her American 'forefather' in which he bequeathed 'ten young negros' and 'my great Bible and all my law books' to his son. Wire
(1998:291) responded: What do I do with such a heritage? Change my name? Hide this page and read the rest to my grandson? But what is shameful should be heard. This is family history, mine and that of others descended from those who were enslaved, and I must go through it rather than around it. Likewise Paul and the enslaved people whose lives shaped his writings are our collective family history. The shame and the glory are tangled, and this 'mess of pottage' is our precious heritage. 'love-patriarchalism'. One can, however, agree with Syreeni (2003:419) that the Pauline and deutero-Pauline heritage is 'ambiguous' to say the least. ${ }^{21}$

To me, the tenets 'faith alone', 'dying with Christ' and a 'renewal of life' which appear alongside patriarchal household codes in some post-Pauline letters could be regarded - to use Troeltsch's (1912:67) term Vorbereitung - as a preparation for and a foreshadowing to what became a hierarchical ecclesial structure, ${ }^{22}$ previously referred to as 'early Catholicism' (Frühkatolizismus) (cf. Elliott 1969:213223). The Liebesidee [love for one another] in these codes refers back to what I call 'imitating Paul' (Van Aarde 1996:261), a Vorbild- und Nachahmungsgedanke (Trilling 1980:147), and what Burridge (2007:144-148) calls 'imitating Christ'. But, anomalously, it also refers forward to a 'reversal of powers' (Theissen 1999:98-99), that is paramount to an alienation from Paul and Jesus. Thus, the appeal remains: does the Sache Jeus geht weiter? Burridge (2007:137), referring to Horrell (1999:330) who states that 'the reciprocity evident in Colossians and Ephesians', disappears in the other New Testament lists (Pastoral letters) and on in the work of the patristic fathers. Horrell points out that the 'focus shifts away from the household to a more hierarchical and church-based model' (cf. Burridge 2007:137).

The Sache Jesu, however, precedes this tendency towards institutionalisation both chronologically and qualitatively. ${ }^{23}$ 'Faith alone' 'deconstructs patriarchalism and apocalyptic retribution'. From the historical Jesus, to Paul, to the change agents in some post-Pauline writings - such as Colossians and Ephesians - 'faith alone' encompasses what the Jesusgroup already is and that it should keep becoming what it already is. The message is: 'put off the old nature' and 'put on the new nature' (Col 3:9-10). ${ }^{24}$ The change agent in Ephesians repeats it: 'put off' and 'put on' (Eph 4:22-24). It is said by Paul in Galatians: if they are baptised in Christ, they have 'put on' Christ (Gal 3:27). In his last known letter, Romans, the Jesus-prophet, Paul, says again: 'put on the Lord Jesus Christ' (Rom 13:14).

\section{Resumé}

This article contests that the author of Colossians preserves though modifies a bit, however with far-reaching consequences - a key element of commonality between

21.See Spjut (2013) who exposes the so-called 'Protestant historiographic myth' as if the 'opponents' in Colossae represented simply either an in-group or out-group heritage.

22.Duling (2003:265): In the literature of the Jesus Movement, household codes are first found in the late first and early 2 nd century, that is, in the generations after Paul. Such literature includes the Church Fathers (1 21:6-9; Polycarp To the Philippians 4:1-6:3; Ignatius To Polycarp 4:1-6:1; Didache 4:9-11; Barnabas 19:5-7) ... (emphasis original).

23.The grammatical preposition behind in the expression 'The Sache Jesu as the canon-behind-the canon' alludes, according to Marxsen (1968:282-284), to both material and chronological priority (cf. Devenish 1992:xii; in Marxsen 1992: xixxxv).

24.Lohse ([1968] 1971:103): 'Putting off the body of flesh, however' - and the author of Col makes this point clear - does not mean contempt for earthly life. Rather it means being active in this life in obedience to the Lord: 'put off the old man with means being active in this life in obedience to the Lord: 'put off the old man with
his practices, and put on the new man, who is being renewed in knowledge according to the image of his creator'. 
Jesus and Paul. Many of the key figures in early Jesus movements are seen as change agents. The article suggests that a social-scientific model of change agency can help exegetes and theologians address questions that historical and literary interpretations cannot. It proposes that historical Jesus and Pauline scholars ought to consider adopting the sequence of generations to complement historical-critical approaches that utilise a chronological stratification of texts. It seeks a way of considering the continuity between Jesus and Paul. With the Lutheran reformation in the 16th century as background, the article introduces the concept of 'by faith alone' from the Pauline letters. By this expression is meant an undivided fidelity to an inclusive approach to understanding God's work, with concrete historical roots in Jesus' crossing of gender, ethnic and cultural boundaries. Living in this manner requires reformation, transformation and change. The article spells out in fuller detail what is understood 'by faith alone' by discussing the meaning of 'faith' within its semantic domain embedded in the codes of 1st-century Mediterranean culture. Living in faith is both a change of one's inner convictions and about a life in faith. The article aims to argue that both Paul and Jesus reject boundaries related to tradition, culture, cult and ethnicity. Following the work of Bruce Malina and John Pilch on change agents, it reads Paul as a 'Jesus-group prophet' who transcended the interests of individuals belonging to the in-group, but also the interests of the whole in-group which tended to exclude the out-group. This is a reading which differs substantively from Malina and Pilch. It is at this point that the article locates the commonality of Jesus and Paul, specifically with regard to transcending an in-group mentality and adopting radical inclusivity and love as the distinctive ethical values of the Jesus-group. Finally, the article argues that in those places where 'faith-alone' as undivided loyalty was not the regnant position within an early Jesus group, two alternative positions arose: an apocalyptic retribution mentality regarding the out-group and the deinstitutionalisation of the Jesus-group in terms of patriarchal and hierarchical 'in house' systems. It shows that Colossians fit within a limited number of texts (Col, Eph, $1 \mathrm{Pt}$ ) that demonstrate both Paul's resurrection faith and his opposing of patriarchal household codes. Seven characteristics of change agents are described. The article explains how each of them is relevant to the interpretation of Colossians. It demonstrates how the author of the letter to the Colossians convinces the group that change is vital, exchanges information with the group, motivates them to change (based on Jesus' having been resurrected and the recipients' sharing in Jesus' resurrection through baptism), identifies matters of concern, initiates change and stabilises continuity within the group (hereby appealing for all forms of discrimination to be removed, a characteristic of the Jesus tradition). Finally, the article discusses the termination of the relationship by noting that the author of Colossians hedges his bet to some extent by including the household code. This reinsertion of distinctions moves away from Paul and in the direction of 'love-patriarchalism'. The article's contention is that 'faith alone' (undivided loyalty) rejects both patriarchalism and love-patriarchalism.

\section{Acknowledgements Competing interests}

The author declares that he has no financial or personal relationships which may have inappropriately influenced him in writing this article.

\section{References}

Allison, D.C., 1982, 'The Pauline epistles and the Synoptic Gospels: The pattern of the parallels', New Testament Studies 28, 1-32. https://doi.org/10.1017/S002868 8500007232

Bird, M.F., 2006, 'The peril of modernizing Jesus and the crisis of not contemporizing the Christ', Evangelical Quarterly 78(4), 291-312.

Bourdieu, P., [1972] 1977, Outline of a theory of practice, transl. R. Nice, Cambridge University Press, Cambridge.

Brown, J.R., 2012, 'Christ's obedient slave: Paul's use of ethos in Romans 1:1-17', RAMIFY: The Journal of the Braniff Graduate School of Liberal Arts 3(1), 62-77, viewed 15 February 2016, from www.ramify.org/issues.php

Bruce, F.F., 1952, 'Justification by faith in the non-Pauline writings of the New Testament', The Evangelical Quarterly 24(2), 66-77.

Bruce, F.F., [1958] 1959, 'The Dead Sea Habakkuk scroll', The Annual of Leeds University Oriental Society 1, 5-24.

Bruce, F.F., [1963] 1985, The letter of Paul to the Romans: An introduction and commentary, Eerdmans, Grand Rapids, MI (The Tyndale New Testament Commentaries).

Bultmann, R., [1928] 1969, 'The significance of the historical Jesus for the theology of Paul', in ed. R.W. Funk (ed.), Faith and understanding, transl. L.P. Smith, vol. I, pp. 220-246, SCM Press, London.

Bultmann, R., 1965, 'Antwort an Ernst Käsemann', in R. Bultmann (ed.), Glauben und Verstehen, Band IV, pp. 190-198, Mohr Siebeck, Tübingen.

Burridge, R.A., 2007, Imitating Jesus: An inclusive approach to New Testament ethics, William B. Eerdmans Publishing, Grand Rapids, MI.

Caldwell, R., 2003, 'Models of change agency: A fourfold classification', British Journa of Management 14(2), 131-142. https://doi.org/10.1111/1467-8551.00270

Collins, R.F., 1988, Letters that Paul did not write: The Epistle to the Hebrews and the Pauline Pseudepigrapha, Michael Glazier, Wilmington, DE (Good News Studies 28)

Crook, Z., 2004, 'BTB readers guide: Loyalty', Biblical Theology Bulletin: A Journal of Bible and Theology 34, 167-177. https://doi.org/10.1177/01561079040340040501

Crook, Z., 2005, 'The divine benefactions of Paul the client', Journal of Greco-Roman Christianity and Judaism 2, 9-26.

DeMaris, R.E., 1994, The Colossian controversy: Wisdom in dispute at Colossae, Sheffield Academic Press, Sheffield (Journal for the Study of the New Testament Supplement Series 96)

de Saussure, F., [1916] 1983, Course in general linguistics, C. Bally \& A. Sechehaye (eds.), transl. R. Harris, Open Court, Chicago, IL.

Devenish, P.E., 1992, 'Introduction: The Jesus-kerygma and the Christian theology', in W. Marxsen (eds.), Jesus and the church: The beginnings of Christianity, pp. xixxxv, Trinity Press International, Philadelphia, PA.

Dewey, A.J., Hoover, R.W., McGauchy, L.C. \& Schmidt, D.D., 2010, The authentic letters of Paul: A new reading of Paul's rhetoric and meaning, Polebridge Press, Salem, OR.

Duling, D.C., 2003, The New Testament: History, literature, and social context, 4th edn., Wadworth/Thomson Learning, Belmont, CA.

Dunn, J.D.G., 1988, Romans 9-16, vol. 2, Word, Dallas, TX (WBC 38b).

Dunn, J.D.G., 1990, 'Paul's knowledge of the Jesus tradition: The evidence of Romans', in K. Kertelge (ed.), Christus bezeugen: Für Wolfgang Trilling, pp. 193-207, Herder, Freiburg.

Dunn, J.D.G., 2009, Beginning from Jerusalem: Christianity in the making, vol. 2, William B. Eerdmans Publishing, Grand Rapids, MI.

Dunson, B.C., 2012, Individual and community in Paul's letter to the Romans, Mohr Siebeck, Tübingen.

Elliott, J.H., 1969, 'A Catholic Gospel: Reflections on "Early Catholocism" in the New Testament', Catholic Biblical Quarterly 31, 213-223.

Elliott, J.H., 2002, 'Jesus was not egalitarian: A critique of an anachronistic and idealist theory', Biblical Theology Bulletin 32(3), 75-93. https://doi.org/10.1177/014610 790203200206

Elliott, J.H., 2003, 'The Jesus movement was not egalitarian but family oriented', Biblical Interpretation 11(2), 173-210. https://doi.org/10.1163/15685150376566 1276

Elliott, J.H., 2007, 'Jesus the Israelite was neither a "Jew" nor a "Christian": On correcting misleading nomenclature', Journal for the Study of the Historical Jesus 5(2), 119-154. https://doi.org/10.1177/1476869007079741

Esler, P., 2003, Conflict and identity in Romans: The social setting of Paul's letter, Fortress Press, Minneapolis, MN.

Giddens, A., 1976, New rules of sociological method, Hutchinson, London. 
Hahn, F., [2002] 2005, Theologie des Neuen Testaments, Band 1. Die Vielfalt des NeuenTestaments: Theologiegeschichte des Urchristentums, 2, durchgesehene und ein Sachregister ergänzte Auflage, Mohr Siebeck, Tübingen.

Heliso, D., 2007, Pistis and the Righteous One: A study of Romans 1:17 against the background of Scripture and the Second Temple Jewish literature, Mohr Siebeck, Tübingen.

Hoffmann, G., 1983, Luther and justification, Reformation Lectures at Bethany Lutheran Theological Seminary and Bethany Lutheran College, Mankato, MN.

Horrell, D.G., 1999, 'Leadership patterns and the development of ideology in early Christianity', in D.G. Horrell (ed.), Social-scientific approaches to New Testament interpretation, pp. 309-337, T \& T Clark, Edinburgh.

Jewett, R., 2007, Romans: A commentary, Fortress Press, Minneapolis, MN (Hermeneia).

Jüngel, E., 1962, Paul und Jesus, JCB Mohr, Tübingen.

Jüngel, E., [1990] 1995, 'The dogmatic significance of the question of the historical Jesus', in E. Jüngel, Theological essays, II, pp. 82-119, edited with an introduction by J.B. Webster and transl. A. Neufeldt-Fast \& J.B. Webster, T \& T Clark, Edinburgh.

Koester, H., 2007, Paul \& his world: Interpreting the New Testament in its context Fortress Press, Minneapolis, MN.

Lohse, E., [1968] 1971, Colossians and Philemon: A commentary on the epistles to the Colossians and to Philemon, H. Koester (ed.), transl. W.R. Poehlmann \& R.J. Karris, Fortress Press, Minneapolis, MN (Hermeneia)

Louw, J.P. \& Nida, E.A., 1988, Greek-English lexicon of the New Testament based on semantic domains, Volume 1: Introduction and domains, United Bible Societies, New York.

Luther, M., [1515-1516] 1961, Lectures on Romans, transl. and ed. W. Pauck, SCM Press, London (Library of Christian Classics).

Luther, M., [1531] 1911, 'Galatenvorlesung (cap. 104)', in D. Martin Luthers Werke: Kritische Gesamtausgabe, 40. Band, Weimar 1883-1929, Weimarer Ausgabe, Herman Böhlaus Nachfolger, viewed 09 June 2016, from https://archive.org/ details/D.Martin Luthers Werke Weimarer Ausgabe.

Luther, M., [1538] 1955, 'Commentary on Galatians (1538)', transl. H.J.A. Bouman, 'The doctrine of justification in the Lutheran confessions', Concordia Theological Monthly 26(11), 801-919.

Malina, B.J., 2002, 'We and they in Romans', HTS Theological Studies 58(2), 608-631. https://doi.org/10.4102/hts.v58i2.566

Malina, B.J. \& Pilch, J.J., 2006, Social-science commentary on the letters of Paul, Fortress Press, Minneapolis, MN.

Malina, B.J. \& Pilch, J.J., 2013, Social-science commentary on the Deutero-Pauline Letters, Fortress, Minneapolis, MN.

Marxsen, W., 1968, Das Neue Testament als Buch der Kirche, Gütersloher Verlagshaus Gerd Mohn, Gütersloh.

Marxsen, W., 1976, 'Jesus - Bringer oder Inhalt des Evangeliums?', in W. Marxsen (ed.), Die Sache Jesu geht weiter, pp. 45-62, Gütersloher Verlagshaus Gerd Mohn, Gütersloh.

Moxnes, H., 1988, 'Honour and righteousness in Romans', Journal for the Study of the New Testament 22, 61-77. https://doi.org/10.1177/0142064X8801003204

Neirynck, F., 1986, 'Paul and the sayings of Jesus', in A. Vanhoye (ed.), L'Apôtre Paul: Personalité, style et conception du ministère, pp. 265-321, Leuven University Press, Leuven (BEThL 73).

Pilch, J.J., 2011, 'Paul: A change agent: Model for the twenty-first century', in P. Spitaler (ed.), Celebrating Paul: Festschrift in honor of Jerome Murphy-O' Conner, O.P., and Joseph A Fitzmeyer, S.J., pp. 81-99, Catholic University Press (Catholic Biblical Quarterly, Monograph Series 48).

Ritschl, A., [1882] 1972. 'Instruction in the Christian religion', reprinted from Three essays, copyright Philip Hefner, and republished in The historical Jesus quest: Landmarks in the search for the Jesus of history, G.W. Dawes (ed.), 1999, pp.
154-171, Westminster John Knox Press, Louisville, KY. [Original German: 1882, Die christliche Lehre von der Rechtfertigung und Versöhnung, Marcus Verlag, Die christh
Bonn].

Rogers, E.M. \& Shoemaker, F.F., 1971, Communication of inovations: A cross-cultural approach, Free Press, Florence, MA.

Schottroff, L., [1985] 1999, “"Not many powerful”: Approaches to a sociology of early Christianity', in D.G. Horrell (ed.), Social-scientific approaches to New Testament interpretation, pp. 275-287, T \& T Clark, Edinburgh.
Sewell, W.H., Jr., 1992, 'A theory of structure: Duality, agency, and transformation' American Journal of Sociology 98(1), 1-29. https://doi.org/10.1086/229967

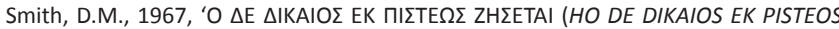
ZESETAI', in B.L. Daniels \& M.J. Suggs (eds.), Studies in the history and text of the New Testament in honor of Kenneth Willis, pp. 13-25, University of Utah Press, Salt Lake City, UT (Studies and Documents 29).

Spjut, P., 2013, 'Problematizing the "Protestant historiographic myth" applied to boundary demarcations and the making of Paulinism in Colossians', Study assignment Biblical studies C2NTs, with J.A. Kelhoffer as supervisor, Uppsala Universitet, viewed 20 February 2016, from http://www.diva-portal.se/smash/ get/diva2:643730/FULLTEXT01.pdf

Stefon, M., 2011, Christianity: History, belief, and practice, Britannica Educational Publishing, New York.

Stuckenbruck, L.T., 2005, 'Colossians and Philemon', in J.D.G. Dunn (ed.), The Cambridge companion to St Paul, pp. 2817-3191, Kindle edn., Cambridge University Press, Cambridge.

Stuhlmacher, P., 1983, 'Jesustradition im Römerbrief? Eine Skizze', Theologische Beiträge 14, 240-250.

Syreeni, K., 2003, 'Paul and love patriarchalism: Problems and prospects', In die Skriflig/In Luce Verbi 27(3), 395-422. https://doi.org/10.4102/ids.v37i3.475

Theissen, G., [1979] 1989, Studien zur Soziologie des Urchristentums, 3. erweiterte Auflage, J.C.B. Mohr (Paul Siebeck), Tübingen.

Theissen, G., 1982, The social setting of Pauline Christianity, transl. J.H. Schütz, T \& T Clark, Edinburgh.

Theissen, G., 1995, "Urchristlicher Liebeskommunismus: Zum "Sitz im Leben" des Topos in Apg. 2, 44 und 4, 32', in T. Fornberg \& D. Hellholm (eds.), Texts and contexts: Biblical texts in their textual and situational contexts, pp. 689-711, Scandinavian University Press, Oslo.

Theissen, G., 1999, A theory of primitive Christian religion, transl. J. Bowden, SCM Press, London.

Thompson, M., 1991, Clothed with Christ: The example and teaching of Jesus in Romans 12:1-15:13, Sheffield Academic Press, Sheffield (JSNT Sup 59).

Trilling, W., 1980, Der Zweite Brief an die Thessalonicher, Benziger Verlag, Zürich (Evangelisch-Katholischer Kommentar zum Neuen Testament XIV).

Troeltsch, E., 1912, Die Soziallehren der christlichen Kirche und Gruppen: Gesammelte Schriften, Band 1, J.C.B. Mohr (Paul Siebeck), Tübingen.

Vaino, O.-P., 2008, Justification and participation in Christ: The development of the Lutheran doctrine of justification to the Formula of Concord (1580), Brill, Leiden.

Van Aarde, A.G., 1996, 'The second letter to the Thessalonians: Reread as pseudepigraph', The Journal of Higher Critical Studies 3(2), 237-266.

Van Aarde, A.G., 2001, 'The "cause of Jesus" (Sache Jesu) as the canon behind the canon', HTS Theological Studies 57(1\&2), 148-174. https://doi.org/10.4102/hts. v57i1/2.1850

Van Aarde, A.G., 2012, 'Paul's version of "turn the other cheek" - Rethinking violence and tolerance', in J.W. Van Henten \& P.G.R. De Villiers (eds.), Coping with violence in the New Testament, pp. 43-68, Brill, Leiden (Studies in Theology and Religion).

Van Aarde, A.G., 2014, 'Pragmatic dimensions in parable research and the divine economy of the basileia', HTS Teologiese Studies/Theological Studies 70(1), Art. \#2688, 1-11. https://doi.org/10.4102/hts.v70i1.2688

Van Aarde, A.G., 2015, 'Christian ethics from the perspective of neighbourly love: Rudolf Bultmann and Stoic ethics', HTS Teologiese Studies/Theological Studies 71(3), Art. \#2870, 1-12. https://doi.org/10.4102/hts.v71i3.2870

Wallis, W.B., 1973, 'The translation of Romans 1:17: A basic motif in Paulinism', Journal of the Evangelical Theological Society 16(1), 17-23.

Walter, N., 1985, 'Paul und die urchristlichen tradition', New Testament Studies 31, 501-502. https://doi.org/10.1017/S0028688500012054

Wenham, D., 1995, Paul: Follower of Jesus or founder of Christianity? William B. Eerdmans Publishing, Grand Rapids, MI.

Wilson, W.T., 1991, Love without pretense: Romans 12:9-21 and Hellenistic-Jewish wisdom literature, Mohr-Siebeck, Tübingen, (WUNT 46).

Zerbe, G., 1992, 'Paul's ethic of nonretaliation and peace', in W.M. Swartley (ed.), The love of enemy and nonretaliation in the New Testament, pp. 177-222, Westminster, Louisville, KY. [Reprinted and expanded in Zerbe, G., 1993, Nonretaliation in early Jewish and New Testament texts: Ethical themes in socia contexts, Sheffield Academic Press, Sheffield (JSNTSuppl)]. 